ENCYCLOPEDDIE Encyclopédie berbère

BERBERE

$34 \mid 2012$

34| Nemencha - Nybgenii

\title{
Nourriture (Kabylie)
}

\section{Camille Lacoste-Dujardin}

\section{OpenEdition}

Journals

Édition électronique

URL : https://journals.openedition.org/encyclopedieberbere/2762

DOI : $10.4000 /$ encyclopedieberbere. 2762

ISSN : 2262-7197

\section{Éditeur}

Peeters Publishers

\section{Édition imprimée}

Date de publication : 5 octobre 2012

Pagination : 5625-5626

ISBN : 978-90-429-2718-6

ISSN : 1015-7344

\section{Référence électronique}

Camille Lacoste-Dujardin, « Nourriture (Kabylie) », Encyclopédie berbère [En ligne], 34 | 2012, document N71, mis en ligne le 15 décembre 2020, consulté le 17 février 2022. URL : http://

journals.openedition.org/encyclopedieberbere/2762 ; DOI : https://doi.org/10.4000/ encyclopedieberbere. 2762

Ce document a été généré automatiquement le 17 février 2022.

(c) Tous droits réservés 


\title{
Nourriture (Kabylie)
}

\author{
Camille Lacoste-Dujardin
}

1 En pays berbère, se nourrir est partout considéré comme un acte social, par les repas partagés dans la communauté familiale, villageoise ou tribale. Car le partage de nourriture cuisinée par les femmes a valeur de civilisation, d'humanité, opposant ainsi les humains à la sauvagerie.

2 L'élaboration culinaire de la nourriture familiale est en effet, après la mise au monde des enfants, l'une des tâches les plus importantes des femmes qui assurent ainsi la transformation des aliments préparés pour la consommation familiale en de multiples opérations, les unes quotidiennes, comme l'épluchage, le pétrissage, le roulage du couscous en différentes formes de cuissons, et d'autres moins fréquentes, souvent élaborées collectivement, et destinées à la constitution de réserves, comme le tri et l'ensilage des céréales ou des glands grillés. Mais individuelle est leur mouture à la force des bras féminins tournant longuement le lourd moulin à bras domestique de pierre, sauf à en confier les charges exceptionnelles au meunier.

3 La préparation des réserves revient aussi aux femmes qui assurent le séchage et/ou le salage des viandes de conserve de plus rare consommation, comme à l'occasion de sacrifices collectifs. Ces élaborations nourricières comprennent aussi le barattage du beurre, la confection des différentes sortes de pâtes, souvent séchées pour être conservées. Quotidiennement, sont consommés surtout des légumes ou pâtes sous différentes formes, et l'indispensable " galette » ou pain (arrum) cuit sur le feu dans un plat particulier (bufrah « celui qui donne la joie».

4 La nourriture devait être encore souvent, dans un passé récent, complétée de piètres cueillettes: artichauts sauvages, escargots, arbouses et différentes baies, aptes à tromper la faim, surtout celle des enfants - thème récurrent dans les contes -, lors de l'absence d'hommes au foyer. Les meilleures nourritures dignes d'être partagées en famille sont essentiellement les céréales sous forme de semoules, cuisinées sur le feu domestique en beignets, crêpes, galettes et, surtout, en sa forme la plus appréciée : le seksu «couscous", la multiplicité de ses grains gonflés à la vapeur étant symbole d'abondance nourricière. 
5 Ce partage de nourriture élaborée entre les humains est marque de civilisation, à l'opposé de la sauvagerie animale, ou de celle des ogresses solitaires dévoratrices de chair humaine crue. La consommation de la viande a même pu être interdite hors de la communauté familiale, en particulier en dehors des partages communautaires en forme de rites d'abondance, de fécondité qui célèbrent la solidarité communautaire. D'autres interdits peuvent, dans certains villages, concerner d'autres viandes d'animaux élevés au village, et surtout des animaux sauvages non égorgés, tandis que les perdrix, lièvres, voire chacal ou hérisson sont souvent consommés, voire même le sanglier que des jeunes gens osent aujourd'hui consommer.

$6 \rightarrow$ Voir aussi « Alimentation » (A164), EB IV, 1987, p. 472-529.

INDEX

Mots-clés : Alimentation, Ethnologie, Kabylie 